Volume 10 Nomor 1, November 2018, p.016-025

Faculty of Law, Universitas Kristen Maranatha

ISSN: 2085-9945 I e-ISSN: 2579-3520

Nationally Accredited Journal by SINTA

\title{
Indonesian Intellectual Rights Law Perspective : Copyrights as A Fiduciary Collateral
}

\section{Ranti Fauza Mayana}

\section{Daniel Hendrawan}

Faculty of Law, Padjadjaran University

Faculty of Law, Maranatha Christian University

daniel.hendrawan@rocketmail.com

Submitted: 2018-09-03; Reviewed: 2018-09-03; Accepted: 2018-11-22

\begin{abstract}
The development of the business world and investment is very fast. Many people want to invest, but sometimes are constrained by the capital they have. One of the ways to obtain modal is to pledge copyright. Indonesia has Law of the Republic of Indonesia Number 19 Year 2002 About Copyright. In this law copyright has not been considered as a guaranteed item. Along with the development of the era, the government is deemed necessary that copyright can be categorized as objects that can be guaranteed. With the issuance of this new law, one way to obtain capital is to pledge copyright as an object with a fiduciary guarantee institution.
\end{abstract}

Keywords: Copyrights; Fiduciary; Law.

\section{INTRODUCTION}

Our world is entering the era of globalization. Where in the globalization of our activities without regard to the limits of space and territory. Indonesia one of which is also affected by what is said in the current globalization phenomenon. One of the international agreements signed in the framework of globalization Indonesia is ASEAN economic community. Indonesia entered the stage of a free market with neighboring countries in Southeast Asia.

Indonesia is following the free market with the countries of the region in Southeast Asia is of course a little more influence of various factors in the life of the nation. One thing that concerns the life of the people at large is economic growth. Indonesia's 
economic growth may be quite high and continues to rise. Indeed, some predict economic growth in Indonesia can be $7 \%$.

High economic growth needs to be supported by the readiness of people to participate in economic growth. Communities need to engage in economic activities to also achieve maximum economic growth. Lots of people who engage in economic activities by conducting business activities such as for example trade. Trade or business activities of buying and selling can be done locally only in the merchant area is located or where the area is also international trade is not just about one country, but many countries. To do it all, trading is done by the people can not be separated from their capital. Capital is a very important factor in business activities in the community. This capital is often a problem in the community when conducting business.

The problem of capital is sometimes people have a lot of possibilities to do business but lack capital. Lots of parties offering capital loans. One of the things that can be done to overcome this is to do a fiduciary. Fiduciary regarded as one of the security institutions that can protect both creditors and debtors. This can be done because the fiduciary debtor can borrow money and also the creditor can obtain collateral in the form of moving goods. It is quite unique in this fiduciary is within its remit fiduciary pledged goods remain on the goods owners or creditors. It is intended to allow the debtor can still work if the pledged goods are goods that are also used for the business of the debtor.

There are so many items that can be used for the fiduciary. One of the things that can be used to guarantee the fiduciary institution is Copyright. In the latest legislation of copyright, namely Law No. 28 Year 2014 About Copyrights said that copyright is movable and intangible, so in this case the copyright can be used as collateral in fiduciary institution. In Indonesia copyright that could serve as fiduciary is something new. This provision would researched laws regarding the implementation of copyright is secured by the fiduciary institution.

\section{DISCUSSION}

\section{Law of guarantees}

Term assurance is a translation of the term zekerheid or cautie, ie the ability of borrowers to meet or pay off debts to creditors, conducted by holding certain objects that have economic value as a dependent on a loan or debt that the debtor received against creditors. ${ }^{1}$ Salim HS provides guarantees legal formulation is the overall legal rules governing the relationship between the giver and the recipient of the guarantee in relation to the imposition of a guarantee to secure credit facilities. ${ }^{2}$

\footnotetext{
${ }^{1}$ Rachmadi Usman, Hukum Jaminan Keperdataan, Jakarta: Sinar Grafika, 2008, hlm. 66.

${ }^{2}$ Salim HS, Perkembangan Hukum Jaminan Di Indonesia,Cetakan Kelima, Jakarta: Rajawali Pers, 2011 hlm. 22
} 
Sri Soedewi Masjhoen Sofwan said that the law guarantees is set juridical construction which allows the provision of credit facilities, to ensure objects are bought as collateral. Regulation should therefore be quite convincing and provide legal certainty for the credit institutions, both domestically and abroad. The existence of such security institutions and agencies, would be accompanied by the credit institution with the number, large, with a long period of time and a relatively low interest. ${ }^{3}$

According to J. Satrio in his book Law of Guarantees Developments in Indonesia, the law guarantees defined as: "The law governing credit guarantees a creditor against a debtor" ${ }^{4}$. According to Rachmadi Usman, the terms of the good guarantee is $:^{5}$

1. Can be easily help gain credit by the party in need;

2. Do not weaken the potency (strength) of the debtor to perform or continue its operations.

3. Provide assurance to the lender, in the sense that the collateral available to be executed at any time, if necessary, can easily be cashed to pay off debts of the debtor.

Douglas W. Arner in the Texas International Law Journals "Property Rights, Collateral, Creditor Rights, and Insolvency in East Asia", to mention some of the main functions of credit guarantees is Principal Functions of Collateral: ${ }^{6}$

1. Mitigation or substitution in credit risk for a potential financier;

2. Change in capital asset use to make financing available;

3. Signal credit risk strengths or borrower status;

4. Signal risk or bargaining weaknesses;

5. Facilitate credit substitution;

6. Effect on costs and information for credit creation;

7. Provide financiers with known credit risks;

8. Encourage contractual compliance by collateral provider .

In the Indonesian law recognizes two types of collateral that is:

a. material guarantee

According to J. Satrio, in his book entitled "The Law of Guarantees, Rights Guarantees material" mentioned that the material has a specific security rights, namely: ${ }^{7}$

\footnotetext{
${ }^{3}$ Ibid, hlm. 5

${ }^{4}$ J. Satrio, Hukum Jaminan,Hak-Hak Jaminan Kebendaan, Bandung: Citra Aditya Bakti, 2007, hlm. 3

${ }^{5}$ Rachmadi Usman, Op.Cit, hlm. 70

6 Douglas W. Arner, "Property Rights, Collateral, Creditor Rights and Insolvency in East Asia", Texas International Law Journals, Vol. 42, No. 515. p. 527

${ }^{7}$ J. Satrio., Op. Cit, hlm.12-13
} 
1. Having a direct connection with or on certain objects belonging to the debtor;

2. Can be maintained or addressed to anyone;

3. Having the nature of droit de suite, it means the right to follow the object in the hands of anyone being;

4. The older ones have a higher position;

5. Can be transferred or transferred to other persons.

b. individual guarantee

Immaterial or individual guarantee is the right that gives the lender a better position, because there is more than one debtor billable. The existence of more than one debtor, and the debtor could be because there bear responsibility for their person or third party unites himself as borg.

One of the types on material guarantee is fiduciary. Fiduciary according to his origin comes from the word "Fides", which means trust, In accordance with the meaning of the word is the relationship (legal) between debtors (authorizer) and creditor (endorsee) is a legal relationship based on trust. ${ }^{8}$

\section{Fiduciary}

According to Article 1 of Law No. 42 of 1999 on Fiduciary, fiduciary is defined as a transfer of ownership of an object on the basis of trust with the provision that the object ownership rights transferred remains in the control of the owner of the object. Fiduciary is security rights over movable goods both tangible and intangible and immovable particular building that can not be burdened security rights as stipulated in Law No. 4 of 1996 on mortgage which remain in control of the Giver Fiduciary, as collateral for the repayment of certain debt, which gives precedence to the receiver position Fiduciary against other creditors.

Fiducia cum creditare contractâ which means the promise of trust made by creditors, debtors dikatakan.bahwa transfer the ownership of an object to a creditor as security for the debt with creditors agreement that will transfer the ownership back to the debtor if the debt has been paid in full. ${ }^{9}$ Fiduciary in Indonesian is also called "handover of property rights in trust". In the Dutch terminology often referred to as the full form of Fiduciare Eigendonts Overdracht (FEO), whereas in the English language is complete is often referred to as Fiduciary Transfer of Ownership. Basically fiduciary is an agreement accessoir between debtors and creditors whose contents statement surrender property rights in trust over movables belonging to the debtor to the creditor, but the objects are still controlled by the debtor as a borrower disposable

\footnotetext{
${ }^{8}$ Gunawan Widjaya dan Ahmad Yani, Jaminan Fidusia, Jakarta: Raja Grafindo Persada, 2001, hlm. 113
}

${ }^{9} \mathrm{Ibid}$, hlm. 114. 
and intended only for the guarantee of repayment of money loan. For the delivery of which is in constitutum possesorium (verklaring van hounderschap) means submission to resume control over the objects concerned because these objects are still in the hands of the debtor. ${ }^{10}$

Fiduciary is a term that has long been known in the Indonesian language. Legislation that specifically regulates this matter, namely Law No. 42 of 1999 on Fiduciary also use the term "fiduciary". Thus, the term "fiduciary" is already an official term in the world of our law. However, sometimes in Indonesian for the fiduciary is also called "Delivery Properties In Trust". In the Dutch literature fiduciary is known also in terms of the following $:^{11}$

1. Zekerheids-eigendom (muniments as a guarantee).

2. Bezitloos Zekerheidsrecht (collateral without the Mastering).

3. Verruimd Pand begrip (Pawn Expanded).

4. Eigendom Overdracht tot Zekerheid (Delivery Properties - is a guarantee).

5. Bezitloos Pand (Pawn without Mastery).

6. Een Pand Verkapt Recht (Pawn sheathed).

7. Uitbaouw of Pand (Pawn Expanded).

The transfer of rights in the construction of the law to be valid, it must meet the following requirements: ${ }^{12}$

1. There is an agreement that is zakelijk.

2. The Fitel for a transfer of rights.

3. The existence of the authority to control the objects of the person submitting the object.

4. particular way for delivery, by way constitutum posessorium for moving tangible objects, or by cessie for accounts payable.

Objects as objects of fiduciary under Article 1 of Law No. 42 of 1999 on Fiduciary is: "Matter is anything that can be owned and transferred both tangible and intangible, registered and unregistered, moving or not moving can not be encumbered encumbrance or mortgages".

The objects of fiduciary regulated in Article 3 of Law No. 42 of 1999 on Fiduciary does not apply to:

1. Mortgage relating to land and buildings, all the legislation in force determines the collateral for these objects shall be registered;

\footnotetext{
${ }^{10}$ Frieda Husni Hasbullah, Hukum Kebendaan Perdata Hak-Hak Yang Memberi Jaminan, Jakarta: CV Indhill, 2009, hlm. 45-46

${ }^{11}$ Sofwan, Sri Soedewi Masjchoen, Hukum jaminan di Indonesia: Pokok-Pokok Hukum Jaminan dan Jaminan Perorangan. Jakarta. Badan Pembinaan Hukum Nasional. 1977. hlm. 27

${ }^{12}$ Sofwan, Sri Soedewi Masjchoen, Loc Cit.
} 
2. Mortgages on ships registered with a gross tonnage of more 20M3atau size;

3. Mortgages on aircraft; and

4. Pawn.

Objects fiduciary is what objects can be used as collateral with fiduciary burdened. Objects that can be loaded fiduciary namely: ${ }^{13}$

1. tangible moving objects, for example:

a. Motor vehicles such as cars, buses, trucks, motorcycles and others;

b. Machinery plant that is not attached to the land / building factories;

c. The tools of office equipment;

d. Jewelry;

e. Inventories of goods or inventory, inventory, stock merchandise with a list of items mutation;

f. Marine vessels measuring less than $20 \mathrm{M} 3$;

g. Home furnishings such as furniture, radio, television, refrigerators, sewing machines;

h. Agricultural implements such as tractors hijackers rice paddies, water suction machines and others.

2. Goods moving intangibles, for example:

a. money orders;

b. Certificates of deposit;

c. Stock;

d. Bond;

e. bills of lading;

f. Receivables acquired at the time the guarantee was given or acquired later;

g. Time deposit.

3. The results of the object which is the object of moving objects guarantee either tangible or intangible movable goods or immovable outcome of which can not be encumbered encumbrance.

4. Insurance claim in the case of objects that become the object of fiduciary insured.

5. The object did not move particularly buildings that can not be burdened with a security interest that is the property of the apartment units on the land use rights on state land (Act No. 16 of 1985) and the building of houses built on the land of others pursuant to Article 15 of Law No. 5 of 1992 on Housing and Human Settlements.

\footnotetext{
${ }^{13}$ Sutarno, 2005, hlm. 212-213.
} 
6. The objects include receivables that had existed at the time the guarantee was given and receivables acquired later in life.

\section{Copyright}

According Copyright is the exclusive right of the creator that arise automatically based on the principle of declarative after a work embodied in a tangible form without reducing restrictions in accordance with the provisions of the legislation.

\section{Related Works or Discussion}

Under Article 504 the Code of Civil Code ("Civil Code"), the object can be divided into two (2) that is movable and immovable. Regarding immovable, under Article 506 - Section 508 of the Civil Code. As for moving objects, under Article 509 - Article 518 Civil Code. Prof. Subekti, SH In his book Principles of Civil Law (pp. 61-62), an object can be classified in the class of objects that are not moving ( "onroerend") first because of its nature, both for their intended use, and thirdly because it is so determined by enactment legislation. ${ }^{14}$

Furthermore, Subekti explained that while objects do not move because it is the land, including everything that directly or indirectly, because of acts of nature or human activity, coupled closely together with the land. So, for example, a piece of the yard, along with what is contained in the soil and everything what is built on it is fixed (home) and grown in situ (tree), calculated fruit on the trees that have not been taken. Not moving for their intended use, are all that though not seriously be combined with land or a building, intended to follow the land or buildings for a longer period of time, i.e. for example the machines in a factory. Furthermore, is not moving because it is so determined by law, any right or billing on an object that is not moving.

On the other hand, still according Subekti, an object is calculated belonged moving object by its nature or because it is determined by law. An object moving because it is the objects that are not affiliated with, or intended to follow the land or buildings, so for example items of household furniture. Classified as a moving object because the stipulation of the law is for example vruchtgebruik of a moving object, lijfrenten, securities holdings of a trading company, bonds of the state, and so on. ${ }^{15}$

According to Mrs. Frieda Hasbullah Husni, SH, M.H., in his book material Civil Law: Rights of The Giving Pleasure (pp. 43-44), says that for the material is not moving can be divided into three groups: ${ }^{16}$

\footnotetext{
${ }^{14}$ Subekti, Pokok-Pokok Hukum Perdata, Jakarta: Intermasa, 2003, hlm. 61-62

${ }^{15} \mathrm{http}: / /$ www.hukumonline.com/klinik/detail/cl4712/mengenai-benda-bergerak-dan-benda-tidak-bergerak, accesed on 1 june 2016

${ }^{16}$ Hasbullah, Frieda Husni, Hukum Kebendaan Perdata: Hak-Hak Yang Memberi Kenikmatan, Jakarta: Ind-HilCo, 2005, hlm. 43-44
} 
1. The object does not move due to its nature (Article 506 Civil Code) such as soil and everything attached to or incorporated in it, or trees and plants whose roots are embedded in the soil or fruit on the trees that have not been picked, as well as goods -Items mine.

2. The object did not move as intended or intended use (Article 507 Civil Code), for example plants and goods produced, mills, and so on. Also housing and objects attached to a board or wall such as mirrors, paintings, jewelry, and others; then with regard to land ownership such as manure, honey in trees and fish in the pond, and so on; as well as building materials derived from the ruins of the building that will be used again to build the building, and others.

3. The object did not move because of a statutory provision, for example, usufruct, and the right to use the material do not move, devotion land rights, rights of passenger's coral, concessions, etc. (Section 508 of the Civil Code). In addition, according to Article 314 Book of the Law of Commercial Law, ships measuring the gross weight of $20 \mathrm{~m} 3$ and above may be recorded in a register of ships that belongs to the category of objects do not move.

Furthermore, Frieda Husni Hasbullah explains that in order to move material can be divided into two groups: ${ }^{17}$

1. Moving objects because it is objects that can move or be moved such as chickens, goats, books, pencils, desks, chairs, etc. (Article 509 Civil Code). It also includes a movable is ships, boats, mill-mill and bathhouses are mounted on the boat and so on (Article 510 Civil Code).

2. Moving objects because of the provisions of law (Article 511 Civil Code), for example:

a. Usufruct and use rights on movables;

b. The right to the contracted flowers;

c. Of collection or receivables;

d. Shares or share-share in the trade alliance, and others.

According to article 1 paragraph 1 Law of the Republic of Indonesia Number 28 Year 2014 About Copyright, Copyright is the exclusive right of the creator that arise automatically based on the principle of declarative after a work embodied in a tangible form without reducing restrictions in accordance with the provisions of the legislation. According to article 16 paragraph 1 and 3 Law of the Republic of Indonesia Number 28 Year 2014 About Copyright is an intangible moving objects and can be used as objects of fiduciary.

${ }^{17}$ Ibid, hlm. 44-45 


\section{Methods}

The method used in the writing of this study using normative juridical approach. Judicial approach used to analyze various regulations and legislation governing the fiduciary agreement and fiduciary. While the normative approach used to analyze the law not merely as a set of rules of law that are normative, but the law is seen as peritaku society menggejala and patterned in public life, always interacting and relating with the community aspects such as politics, economics, social and cultural rights.

\section{Results}

In the provisions of Law No. 42 of 1999 on Fiduciary not mentioned that copyright can be made into an object fiduciary. If we look at the nature of copyright according to the Law of the Republic of Indonesia Number 28 Year 2014 About Copyright, i.e. movable and intangible, the copyright can be classified by the fiduciary. Act No. 42 of 1999 on Fiduciary as the basis also of the implementation of the Law of the Republic of Indonesia Number 28 Year 2014 About Copyright. To cope with the progress of time is very fast, it can be said that copyright can be a helper for creators can raise capital to develop the creation or also create a new creation.

\section{CONCLUSION}

Implementation of copyright becomes the object of fiduciary can be a problem. The existing problems, the moral rights and exclusive rights. Moral rights and exclusive rights of the copyright holder in which when the copyright was secured by the fiduciary and cannot be repaid. For further research, it will be examined on exclusive rights and moral rights in the event creator cannot pay off its debts to creditors.

\section{REFERENCE}

\section{Books}

Frieda Husni Hasbullah. 2009. Hukum Kebendaan Perdata Hak-Hak Yang Memberi Jaminan. Jakarta: Indhill

Gunawan Widjaya dan Ahmad Yani, Jaminan Fidusia, Jakarta: Raja Grafindo Persada, 2001.

Hasbullah, Frieda Husni, Hukum Kebendaan Perdata: Hak-Hak Yang Memberi Kenikmatan, Jakarta: Ind-Hil-Co, 2005.

J. Satrio, Hukum Jaminan, Hak-Hak Jaminan Kebendaan, Bandung: Citra AdityaBakti, 2007.

Rachmadi Usman, Hukum Jaminan Keperdataan, Jakarta: Sinar Grafika, 2008. 
Dialogia luridica: Jurnal Hukum Bisnis dan Investasi

Volume 10 Nomor 1, November 2018

Salim HS, Perkembangan Hukum Jaminan Di Indonesia,Cetakan Kelima, Jakarta: Rajawali Pers, 2011

Sofwan, Sri Soedewi Masjchoen, Hukum jaminan di Indonesia: Pokok-Pokok Hukum Jaminan dan Jaminan Perorangan, Jakarta: Badan Pembinaan Hukum Nasional, 1977.

Subekti, Pokok-Pokok Hukum Perdata, Jakarta: Intermasa, 2003.

\section{Journals}

Douglas W. Arner, "Property Rights, Collateral, Creditor Rights and Insolvency in East Asia”, Texas International Law Journals. Vol. 42, No. 515.

\section{Internets}

http://www.hukumonline.com 